\title{
Depletion of neuroendocrine cells in rectal biopsy specimens from HIV positive patients
}

\author{
J B McCullough, P A Batman, A R O Miller, P M Sedgwick, G E Griffin
}

\begin{abstract}
Aims: To compare the density of neuroendocrine cells in rectal biopsy specimens from human immunodeficiency virus (HIV) infected individuals with that of a control group.

Methods: Neuroendocrine cells in rectal biopsies were identified using an immunohistochemical stain for chromogranin and subsequently quantified using a method of linear intercept.

Results: Neuroendocrine cells were found to be significantly decreased in the HIV positive group.

Conclusions: Loss of neuroendocrine cells may contribute to apoptotic bodies seen in this condition. This could be related to infection of these cells with HIV and could contribute to diarrhoeal disease in HIV infection.
\end{abstract}

Gastrointestinal symptoms are a common clinical manifestation of HIV infection. Their pathogenesis is multifactorial and in a significant number of patients diarrhoeal disease can be attributed to infection or neoplasia. ${ }^{1}$

In a proportion of patients, however, no opportunistic enteropathogen can be detected and in these cases it has been suggested that pathophysiology may be the result of direct infection of the intestinal mucosa by HIV (HIV enteropathy). ${ }^{2}$ In situ hybridisation has shown that HIV can be present within epithelial cells thought to be of neuroendocrine nature, at the base of duodenal and rectal crypts in biopsies from patients with AIDS. ${ }^{34}$ In an attempt to assess the effects of HIV infection on neuroendocrine cells, we have quantified such cells in rectal biopsies of HIV infected patients.

Department of

Histopathology,

Bradford Royal

Infirmary, Bradford

J B McCullough

P A Batman

Department of

Communicable

Diseases, St George's

Hospital Medical

School, London

A R O Miller

P M Sedgwick

G E Griffin

Correspondence to:

Dr J B McCullough,

Department of Pathology,

Department of Pathology,

Level 6, Ninewells Hosp

and Medical School,
Dundee, DD1 9SY

Dundee, DD1 9SY

Accepted for publication

1 November 1991
STOOL MICROBIOLOGY

Stools from the HIV positive patients were examined microscopically for enteropathogens, and cultured for salmonellae, shigellae, Campylobacter sp, Aeromonas sp, Plesiomonas $\mathrm{sp}$, and Clostridium difficile. Culture on Lowenstein-Jensen medium was also carried out. Microscopic examination included a search for ova and parasites. Ziehl-Neelsen and modified Ziehl-Neelsen stains were used in an attempt to identify mycobacteria, cryptosporidia and isospora.

\section{RECTAL BIOPSIES}

Rectal biopsy specimens were taken from each of these patients and biopsies from eight age and sex matched control subjects were examined in parallel. Control biopsies were from subjects who were not in a high risk group for HIV infection but for ethical reasons HIV antibody testing was not carried out. Biopsies from control subjects were taken during the clinical investigation of diarrhoea and were judged as normal by an independent consultant histopathologist.

The rectal biopsy specimens were fixed in $4 \%$ neutral buffered formaldehyde and processed routinely to paraffin wax. Sections $5 \mu \mathrm{m}$ thick were cut from these blocks and stained with haematoxylin and eosin for subjective light microscopic examination. In addition, each biopsy was stained with periodic acidSchiff (PAS) and by modified Ziehl-Neelsen and Warthin-Starry methods to detect mucosal enteropathogens.

\section{IMMUNOCYTOCHEMISTRY}

Indirect immunoperoxidase staining with a monoclonal antibody to chromogranin was carried out to identify the neuroendocrine cell population in the base of rectal crypts. ${ }^{5}$ Numerous microscopic fields including rectal crypts from each biopsy were subsequently photographed and the percentage of crypt basement membrane occupied by these cells (membrane density) estimated using a method of linear intercept. ${ }^{6}$ Sufficient intercepts with crypt basement membrane were counted in each biopsy to obtain a value for membrane density of neuroendocrine cells with a confidence limit of $95 \%$. Graphs plotting a cumulative mean value for membrane density were constructed for each biopsy to support this estimate of sample size.

\section{STATISTICAL ANALYSIS}

Due to small sample sizes and a skewed distribution in the measurements, the median and semi-interquartile range (SIR), as opposed to the mean and standard deviation, were used as measures of location and spread. Since distributional assumptions could not be made, the non-parametric Wilcoxon two- 
Figure 1 Sections of rectal mucosa from control (A) and HIV positive individual $(B)$ stained by immunoperoxidase method using a monoclonal

antibody to chromogranin. Neuroendocrine cells in crypt epithelium stain positively.

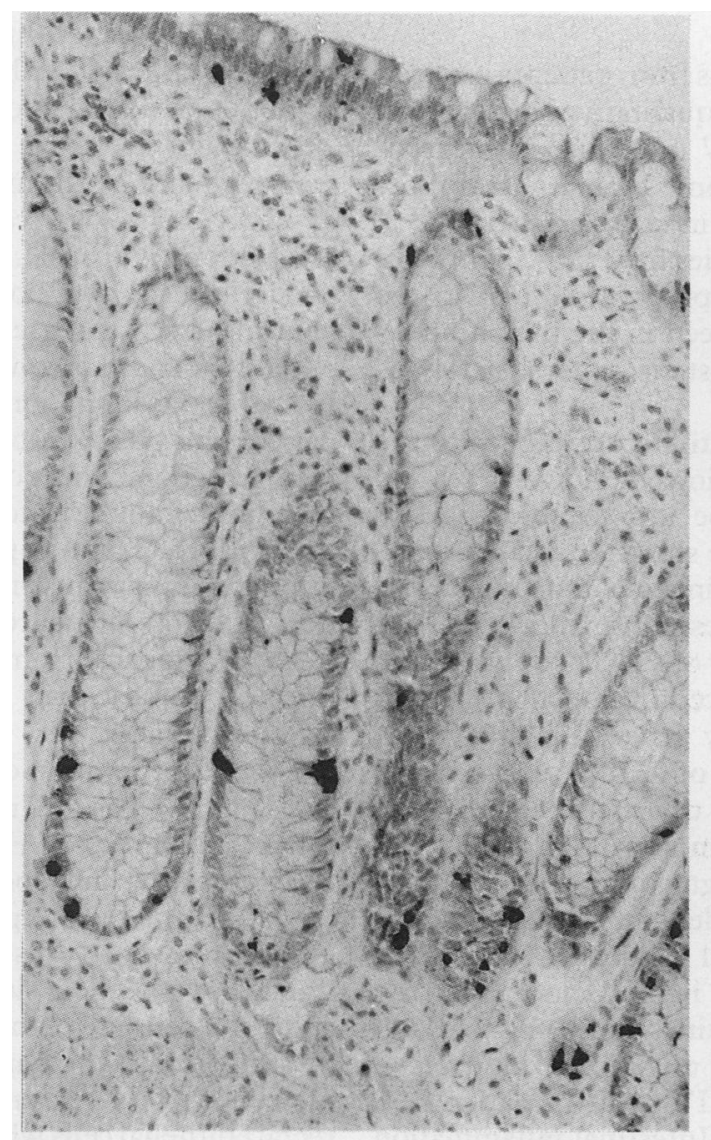

(A)

tailed two-sample test was used to test whether two independent groups had been drawn from the same population.

\section{Results}

MICROBIOLOGY

No enteropathogens were identified on stool examination or culture. Intestinal spirochaetosis, as documented below, in the biopsies of HIV infected individuals was the only mucosally associated enteropathogen detected.

\section{HISTOLOGICAL APPEARANCE}

Mucosal inflammation was present in 15 out of 19 of the HIV positive cases. In three of these cases there were associated epithelial erosions. Inflammation in all these cases was mild and superficial, although in one case there was mild distortion of crypts and crypt abscess formation. None of the specimens showed atrophy of crypts.

Intestinal spirochaetosis was identified on haematoxylin and eosin stained sections and confirmed by Warthin-Starry stain in four out of $19(21 \%)$ of the HIV positive cases, and in none of the controls.

Apoptosis recognised by light microscopy was noted in all biopsies from the HIV positive group. This was a rare feature in control biopsies.

\section{QUANTIFICATION OF THE ENTEROCHROMAFFIN} CELL POPULATION

Neuroendocrine cells stained with monoclonal

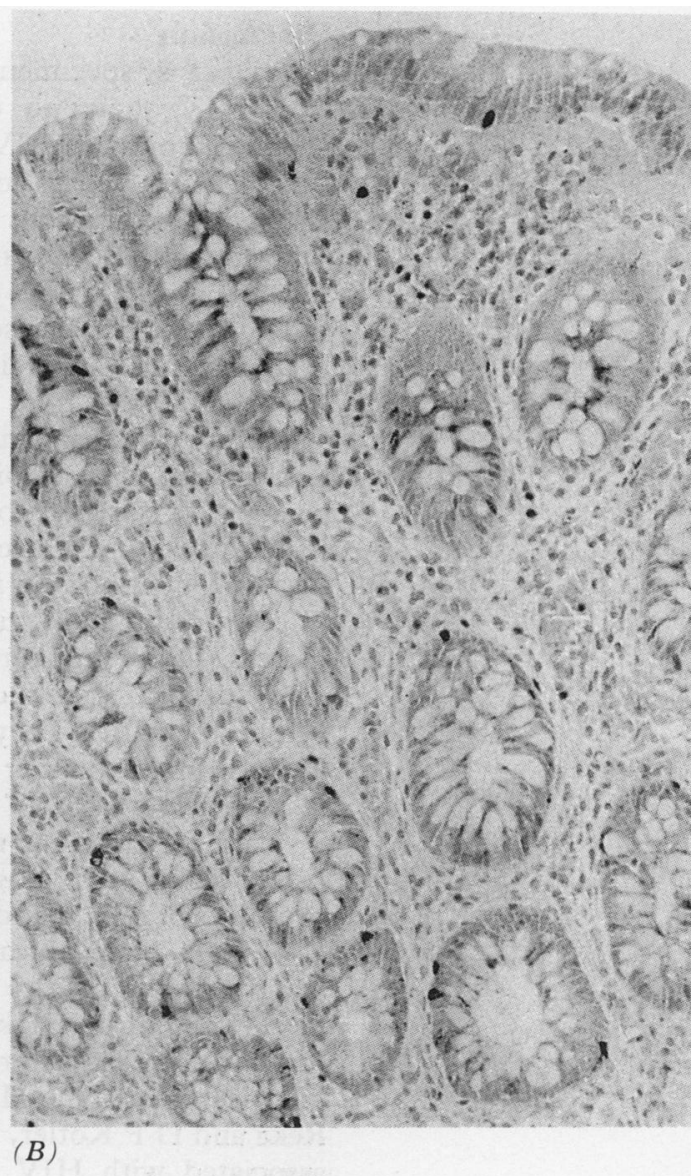

antibody to chromagranin in a biopsy specimen from an HIV positive patient and a control case are shown in fig 1 . The percentage basement membrane occupied by the neuroendocrine cells in rectal biopsies from HIV infected patients and control subjects is shown in fig 2. The percentage of basement membrane occupied by neuroendocrine cells (membrane density) was lower in biopsies from HIV positive individuals than in those from control cases (Wilcoxon test statistic $S=166, \quad p<0.01 ; \quad$ HIV $\quad n=19$, median $=2 \cdot 6$, SIR $=0.85 ;$ controls $n=8$, median $=3 \cdot 75, \mathrm{SIR}=1 \cdot 23$ ). There does not appear to be any correlation between this reduction and clinical stage of HIV disease.

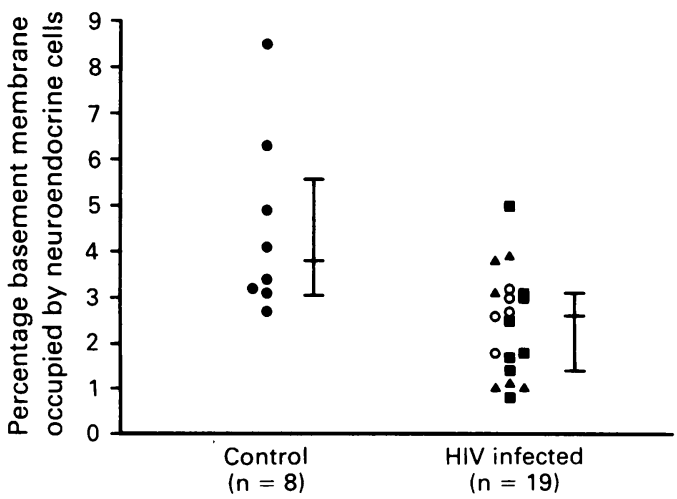

Figure 2 Graph showing membrane density of neuroendocrine cells in HIV positive individuals. The vertical line indicates the median, first, and third quartiles. - controls; O asymptomatic patients; $\square$ ARC/ persistent generalised lymphadenopathy; $\triangle A I D S$. 


\section{Discussion}

Rectal biopsy specimens from patients infected with HIV show no qualitative histological changes typical of HIV infection. Mild proctitis was detected in some biopsies ${ }^{7}$ and most showed apoptotic cells in crypt epithelium. ${ }^{8} \mathrm{~A}$ minority of these biopsies have large lymphoid follicles in the lamina propria, ${ }^{9}$ similar to the follicular hyperplasia seen in the lymph nodes of patients with persistent generalised lymphadenopathy.

A more critical quantitative approach to the examination of rectal biopsies, however, shows changes which may be attributable to HIV itself. Bishop et al have shown increased numbers of T lymphocytes in rectal mucosa of HIV infected individuals, resulting from a marked increase in the number of $\mathrm{CD8}^{+}$suppressor $\mathrm{T}$ cells, despite a reduced number of $\mathrm{CD}^{+}$ helper $\mathrm{T}$ cells. ${ }^{7}$ They have also shown an increase in the number of $\mathrm{CD8}^{+}$cells and a fall in the number of $\mathrm{CD4}^{+}$cells in the aggregate of $T$ cells surrounding mucosal lymphoid follicles, along with fragmentation of the cell processes of follicular dendritic cells. ${ }^{9}$ There is also some biochemical evidence for inflammatory bowel disease in HIV infection: the tissue content of cytokines interleukin- $1 \beta$ and tumour necrosis factor $\alpha$ is increased in rectal biopsies from some HIV positive patients (S Reka and D P Kotler, Intestinal inflammation associated with HIV infection. Sixth International Conference on AIDS, San Francisco, 1990).

HIV is detectable by immunohistochemistry in the lamina propria of rectal biopsies from most infected patients, both in mucosal lymphocytes and macrophages. ${ }^{10}$ Furthermore, one study has shown a correlation between the tissue content of HIV protein p24 in rectal mucosa and the degree of histological inflammation (Reka and Kotler, 1990, see above) HIV may also infect follicular dendritic cells in lymph nodes. ${ }^{112}$ The virus possibly infects such cells in mucosal lymphoid aggregates, which possibly act as a reservoir of infection.

HIV proteins have been shown immunohistochemically in epithelial cells forming a rectal gland ${ }^{3}$ and a colonic carcinoma cell line has been successfully infected with HIV. ${ }^{1314}$ It has been shown by a double staining technique that neuroendocrine cells in rectal mucosa may be one population of epithelial cells that are susceptible to infection by HIV. ${ }^{34} \mathrm{~A}$ section of rectal mucosa from an HIV positive patient was treated with argentaffin stain and the same section subsequently hybridised with a probe specific for HIV RNA. In situ labelling of HIV nucleic acid was localised in argentaffin positive cells at the base of rectal crypts.

This study provides some support for the hypothesis that HIV infects neuroendocrine cells. We have shown, by estimating the proportion of crypt basement membrane supporting neuroendocrine cells in rectal mucosa, that the population of these cells is depleted in HIV positive patients. This effect of HIV infection occurs at all clinical stages of the disease, including asymptomatic subjects. Spirochaetosis was the only opportunistic infection shown in our study group, and this organism appeared to have no influence on the depletion of neuroendocrine cells.

Although we have shown a decrease in neuroendocrine cells in an HIV infected group of individuals, we cannot prove that this association is causal. Depletion of neuroendocrine cells does not appear to be related to clinical stage of disease, and the possibility that other factors are involved cannot be excluded. However, examination of a larger group of patients may show a correlation with stage of HIV infection. This population of homosexual men has common factors in addition to infection with HIV, and in particular anal receptive intercourse may cause rectal trauma, inflammation, and loss of neuroendocrine cells. Study of rectal biopsies from a group of non-HIVinfected homosexuals would therefore be of significant value.

Focal degeneration of epithelial cells (apoptoses) in the base of rectal crypts is the histological hallmark of HIV infection, ${ }^{8}$ although this feature is not specific for HIV disease. Apoptoses in rectal epithelium are typical of graft-versus-host disease ${ }^{15}$ and allogeneic transplant rejection situations in which these epithelial cells are eliminated immunologically by antigenically incompatible cytotoxic T lymphocytes. It is reasonable to speculate that rectal epithelial cells which are infected by HIV may express surface viral antigens which precipitate cell destruction by immunological means. ${ }^{16}$ Similarly, the villous atrophy seen in the jejunum of HIV-infected patients has a morphological resemblance to the changes seen in a graft-versus-host reaction. ${ }^{2}$

Since neuroendocrine cells in rectal epithelium can be infected with HIV, ${ }^{3}$ they could express new surface antigens. These cells could represent some of the rectal crypt cells which are eliminated by apoptosis, and this phenomenon could account for the depletion of neuroendocrine cells. Paradoxically, these cells are spared from destruction in classic graftversus-host disease, ${ }^{47}$ possibly because their proliferation kinetics differ from those of other crypt cells, whereas in other disease states in which apoptoses are a feature, such as ulcerative colitis ${ }^{18}$ neuroendocrine cells appear to increase in density. ${ }^{19}$

Neuroendocrine cells in the bowel produce a variety of peptide hormones which affect gut motility and absorption. ${ }^{20}$ Infection of these cells by HIV and their depletion may contribute to the diarrhoeal illness of HIV disease.

We are grateful to Mr J Chapman and Mr S Toms for their photographic assistance and to Ms J Norwood for her help in preparing the manuscript.

1 Stamm B, Grant JW. Biopsy pathology of the gastrointestinal tract in human immunodeficiency virus associated im disease: a 5 year

2 Batman PA, Miller AR, Forster SM, Harris JR, Pinching AJ, Griffin GE. Jejunal enteropathy associated with human immunodeficiency virus infection: quantitative

histology. J Clin Pathol 1989;42:275-81.
3 Nelson JA, Wiley CA, Reynolds-Kohler C, Reese CE, Margaretten W, Levy JA. Human immunodeficiency virus detected in bowel epithelium from patients with gastrointestinal symptoms. Lancet 1988;i:259-62.

4 Levy JA, Margaretten W, Nelson J. Detection of HIV in 
enterochromaffin cells in the rectal mucosa of an AIDS patient. Am J Gastroenterol 1989;84:787-9.

5 Wilson BS, Lloyd RV. Detection of chromagranin in neuroendocrine cells with a monoclonal antibody. $\mathrm{Am} \mathrm{J}$ Pathol 1984;115:458-68.

6 Aherne WA, Dunill MS. In: Morphometry. London: Edward Arnold, 1982.

7 Bishop PE, McMillan A, Gilmour HM. Immunological study of the rectal mucosa of men with and without human study of the rectal mucosa of men with and without human

8 Kotler DP, Weaver SC, Terzakis JA. Ultrastructural features of epithelial cell degeneration in rectal crypts of patients with AIDS. Am J Surg Pathol 1986;10:531-8.

9 Bishop PE, McMillan A, Gilmour HM. A histological and immunocytochemical study of lymphoid tissue in rectal biopsies from homosexual men. Histopathology 1987;11:1133-47.

10 Jarry A, Cortez A, Rene E, Muzeau F, Brousse N. Infected cells and immune cells in the gastrointestinal tract of AIDS patients. An immunohistochemical study of 127 cases. Histopathology 1990:16:133-40.

11 Armstrong JA, Horne R. Follicular dendritic cells and viruslike particles in AIDS-related lymphadenopathy. Lancet like particles in

12 Tenner-Racz K, Racz P, Bofill M, et al. HTLV-III/LAV viral antigens in lymph nodes of homosexual men with persistent generalised lymphadenopathy and AIDS. $A m$ J Pathol 1986;123:9-15.

13 Adachi A, Gendelman HE, Koenig S, et al. Production of acquired immunodeficiency syndrome-associated retrovirus in human and nonhuman cells transfected with an infectious molecular clone. J Virol 1986;59:284-91.

14 Adachi A, Koenig S, Gendelman HE, et al. Productive persistent infection of human colorectal cell lines with human immunodeficiency virus. J Virol 1987;61:209-13.

15 Gallucci BB, Sale GE, McDonald GB, Epstein R, Shulman HM. Thomas ED. The fine structure of human rectal epithelium in acute graft-versus-host disease. Am J Surg Pathol 1982;6:293-305.

16 Slavin RE. Lymphocyte-associated apoptosis in AIDS, in bone-marrow transplantation and other conditions. Am J Surg Pathol 1987;11:235-8.

17 Lampert IA, Thorpe $P$, van Noorden $S$, et al. Selective sparing of enterochromaffin cells in graft-versus-host sparing of enterochromaffin cells in graft-versus-host disease a

18 Delpre G, Avidor I, Steinherz R, Kadish U, Ben-Bassat M. Ultrastructural abnormalities in endoscopically and histologically normal and involved colon in ulcerative colitis. Am J Gastroenterol 1989;84:1038-46.

19. Gledhill A, Hall PA, Cruse JP, Pollock DJ. Enteroendocrine cell hyperplasia, carcinoid tumours and adenocarcinoma in long-standing ulcerative colitis. Histopathology 1986;10:501-8.

20. Polak JM, Pearse AG, Heath CM. Complete identification of endocrine cells in the gastrointestinal tract using of endocrine cells in the gastrointestinal tract using semithin-thin sections to identify motilin 